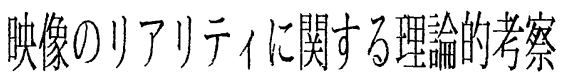

Analysis of Reality in 'Image'

\author{
佐々木和彦 \\ SASAKI Kazuhiko
}

This paper is an analys is of Reality in 'image'. 'Image', here, means represe nted visual images of physical reality by optical instruments. There are tow purposes here:(1)To reveal intrinsic features of the 'image' itself, (2) To consider what kind of sense could be generated by stimulating our sensibility. As for procedure of the concrete analysis, the author first reveals the structure of the representation of 'image', based on semiological interpretation. Secondly, the author analyzes the features of 'inage' and the structure of human sense of sight through a concept introduced hy Benjamin, namely, the optical unconscious'. Finally, the author explores the origins of our sense of reality through image.

1.はじめに

われわれは映像を見る際に、そのリアリティの根拠をよ゙こに置いているのだろうか。本 稿の最終的な目的は、映像によって喚起されるリアリティの本質とは何であるのかという ことを明らかにすることである。しかし、それは映像それ自体が本性的に内在している特 性を探究することと同義である。何故ならば、映像によって喚起されるリアリティの本質 は何かと問うことは、より精確に言うならば、映像を見ることによってわれわれ主体の感 受性に喚起されるリアリティの感覚が、一体映像のどのような特性に由来するものなのか ということ探り当てることにほかならず、そのような探究は映像それ自体の特性を明ら かにすることとパラレルな作業になっているからである。

そこで、われわれはまず初めに、映像は本性的にいかなる特性をそ机自体に内在させて いるのかということを分析し、次いで、その特性はわれわれ映像を見る主体の感受性に対 していかなる地位を持っているのかということを考察し、その上で、われわれが映像を見 ることによって喚起されるリアリティの感覚は何に由来し、その本質は何なのか、という ことを映像それ自体の特性から探究していく。まずその導入として、映像それ自体の特質 を体系的に分析し、客钼的な「学」の体系を提示しようと試みた映像の記号論的研究の意 義とその問題点を見ていくことにする。何故ならば、映像の記号論的研究はその目論見に 反して、記号論に立脚する限りは考察不可能な映像それ自体の特質を逆に浮かび上がらせ たからであり、それは映像の記号論的研究なしには明確に照らし出しえなかった事柄だか らである。尚、われわれが本稿において考察の対象とする映像とは、光学的装置によ一て 表象された害在する事物の視覚的再現像としての「映像（image）」であり、そのような具

成城大学大学院文学研究科コミュニケーション学尃攻博士後期課程 
体的対象の視覚的性質の模像としての映像に議論を限定して分析を進めていく。

\section{2. 映像の記号論的分析}

映像の研究に記号学の方法論を適用する試みは、映像を一つの意味作用の体系として分 析し記述する道を開いた。クリスチャン・メッツをその帮質的な創始者とする映像に対す る記号論的アプローチは、映像における意味作用の過程を分析するにあたって、映像によ って表現されている内容の物語的分析やそのイデオロギー的解釈といった従来の映像研究 に委ねられていたアプローチに対して、構造意味論によって作り上げられた言語学上のモ デルを一つの範型として援用することによって、映像の形式的分析を可能にし、映像を一 つの記号体系としてその構造と機能をより悠密に説明する原理を手にしたと言える。そこ で本章において、映像の記号論的アプローチが映像研究にもたらした理論的認識の地平の 概略を粗描することで、その研究方法の可能性と問題点を兒ていくことにする。

そもそも映像の記号論的分析とはいかなる研究方法を指すのか。最も簡略化して言うな らば、それは映像と言語との表象記号としてのアナロジーを通じて映像をその最も基本的 な単位にまで分解し、抽出された諸単位の機能的な組み合わせの法則に基づいて全体を再 構成することで映像の記号論的体系を樹立しようとする試みにほかならない。従って、そ れは先ず第一に「映像言語」という概念の妥当性を証明しえなければならないのである。 但し、ここで注目しておくべきことは、この研究の目指すところが「映像言語」の体系化 にある以上、映像それ自体へのアプローチが必然的に記号とその読解という解釈学的思考 に基づいて進められ、それ故に映像をあくまで可読のイメージとして分析することになる よいうことである。その最も典型的な例が、映画のフィルム的持続を分節化する最小単位 であるショットを言語体系に扒ける単語に類するものとし、シークエンスを文に類するも のと見做す、クレショフに代表される主張であるが、そのような隠喻に基づく主張は、映 像には言語記号と異なり否定形が存在しないということ、つまり映像は否定文を構成する ことが不可能な記号によって成立している「言語」であるという指摘によってその妥当性 を失わざるをえないだろう[松浦寿輝 1997:146]。エーコが言うように、「誤謬は、隠喻 のこのような経験的な使用から、隠喻に文字どおりの価值を託してこれをまこもにうけと ってしまうというような理論化に移ってゆくとき、始まるのである。」[Eco 1968:訳 7980] しかし、映像という表象記号を言語という表象記号とのアナロジーに基づいて分析を 展開するこよの妥当性は、記号のより根本的な性質を考察することで検討することができ る。

構造㗼語学:の先駆者であるソシュールによるならば、言語記㫕(signe) と住「シニフィ アン（意味するもの：記号表現）」（signifiant）と「シニフィエ（意味されるもの：記号 内容）」(signifié) とから構成されている記号であるが、その項の結びつきが恣意的関 係にあるとされている[Saussure 1916: 訳 98]。この言語記号の恣意性を確認した上で議 論を進めると、ソシュールは言語学の対象をラング（言語体系）上して見出したが、ラン グというものは実在体ではなく、ただそれを語る主体のなかにしか存在しないと言った。 [Saussure 1916: 訳 126,150,171] つまり、ラングとは外在的文脈的なものすなわち実在 的な指示対象 (referent)や想像的な意味作用を現象学的に還元したところに主観性におい て見出される下位構造だということである。このような形式化の作業によってソシュール 
は言語記号は何らかの意味をア・プリオリに表すという伝統的な記号観が前提としていた 「実在(オ川汁ル)とその表象( コピー)」という二項図式を退け、翻って言語が解読可能な記号 として成立し特定の意味を表しうるのは特定言語の特定状態においてシニフィアンとシニ フィエの結びつきが慣習化（物象化）された場合のみであるということを明らかにしたの である。このような言語記号の成立には共同体のコンヴェンションとコードの体系が不可 欠であるという洞察を可能にした記号観が言語記号の恣意性にほかならない。以上のよう な記号観から導き出される帰結として、記号が記号でありうるための条件すなわち記号の 記号性とは、差異性（示差性）にしかなく、必然的に語は差異体系に依存するということ になる。それに対して映像の記号としての構造は、バルトが言うように、シニフィアンと シニフィエの関係か殆ど同語反復的であり [Barthes 1982: 訳 28]、その帰結として、映像 は「コードのないメッセージ」 [Barthes 1982:訳 28]として言わば即自的に存立しうる記 号として、映像それ自体が積極的な多義的解釈に委ねられることになるのである。

ところで、メッツは映像の記号論的研究の先駆とされる論文「映画一言語体系(ラング)か、 言語活動(ランガージュか.」の中で、映画を「言語(ラング)なき言語活動(ランガージュ)」[Mets 1964 :

訳 224] と定義づけたが、そのように言明することの根拠は上述したような映像の記号と しての性格を考虑することで了解することができる。つまり、映像は言語記号と異なりシ ニフィアンとシニフィエの関係か殆ど瘉着状態にあるために、言語においてラングを見出 す際に行われた現象学的還元の作業が不可能である。従って、映像においては言語記号に おけるラングに相当するような映像体系といった下位構造を仮定することはできない。し かし、そうであるからといって映像によって語ることの可能性か総て否定された訳ではな い。メッツは「映像的言説（あるいは「映画作品的言説」）」[Mets 1964 ：訳 237] とい うディスクールの形態が次のような理由から成立可能であると主張しているのである。す なわち、映像の記号上の特性としてのシニフィアンとシニフィエの同語反復的関係に基づ く極めて自然な理解可能性とそのようなショットの連辞的関係（広義のモンタージュ）は、 映像の持続（運動）を通して構成的ダイナミズムを生み出し、そこにある種の効果として 独特の叙述のスタイルを発生させると言うのである[Mets 1964：訳 238, 24T]。

以上のことから、映像の記号論的研究の限界之可能性を指摘することができる。その限 界とは、映像と言語とはその表象記号としての性格（シニフィアンとシニフィエの関係） が根本的に異なるが故に、両者をアナロジーに基づいて研究するためには一定の制限が設 定されなけ扎ばならないということである。何故ならば、そこには理論化の構築過程に伴 う陥突、すなわち映像を言語記号に基づく統語法に当て嵌めていくという転倒した手続き へと落ち込んでいきかねない可能性があるからである。一方その可能性とは、そのラディ カルな形式化の作業によって記号の記号性が問われる地点にまで遡行し、そこから翻って 記号の意味生成過程をより厳密に考察する可能性を開いたということである。たとえば現 代記号論の創始者ともいうべきパースによるならば、記号の意味とはそれによってその記 号が翻訳されうる別の記号のことだとされている[Peirce 1897 : 訳 2]。つまり、ある記 号の意味がそれ自体別の記号で表現されるほかないということは、原理上ある言葉が表現 する意味というものはそれ自体別の言葉で表現されるほかないということであり、本来解 釈の連鎖は無限後退的に続いていくということである。それは言い換えるならば、言語の 自己言及的構造に基づく意味の決定不能性にほかならない。言語の場合、その無限の連鎖 
を断ち切るような「最終的解釈項」は共同体のコンヴェンションとコードの体系、あるい は死のみであるとされているが「Peirce 1868 ：訳 180-181]、それは言語記号の恣意性に 起因しているということは上述した通りである。それに対して映像の場合、そのシニフィ アンとシニフィエの関係か殆ど同語反復的であるために、映像は常に直接表象された対象 を指し示し、解釈の連鎖が無限に続いていくということはありえないが、それは言わば一 義的な解釈を拒むものとしてわれわれの前に提示されることになる。

但しここで留意すべきことは、われわれの意識というものが特定言語の共時文化内にあ るとするならば、バンヴェニストが言うように、シニフィアンとシニフィエの結びつきは 恣意的ではなく必然的であり、「両者はいっしょに私の精神に刷りこまれた。それでどん な場合にも、いっしょに㬇起される」[Benveniste 1966 : 訳 57]というこよである。つま り、われわれが思考し意識するということは勿論のこと、映像に限らず何ものかを見ると いう視覚の働きあるいは知覚作用一般は言語によって分節化されており、そ机故にあらゆ る対象が分節構造を付与されているということである。この点を認識しておくことは極め て重要なことである。何故ならば、あらゆる現象を一つの意味作用の体系之して分析を試 みる記号論的アプローチは、南らゆる対象が言語によって分節構造を付与されている限り で、あるいはそのような事情においてその有効性を発揮しえたと言いうるからである。ま た、われわれの認識というものもまた言語によって分節化されているならば、映像を見る 上いう体験は必然的に読むという行為に還元されることになるだ万う。つまり映像それ自 体へのアプローチが記号とその読解という解积学的思考に基づいて展開され、映像があく まで可読のイメージとして分析を進められるのは、映像の記号論的アプローチの方法上の 問題点であるばかりでなく、上述したような意識の言語的な分節構造にもその原因の一端 があるのだということが照らし出されたからである。

そしてその当然の帰結として、映像研究における分析の対象は、映像によって再現され た内容に限られてくるだろう。映像研究がそのような内容レヴェルの分析に終始している 限り、映像によって喚起されるリアリティの本質は、映像化された内容の象徵体系に見出 されるほかないのだが、われわれか映像を見る際にその内容によって喚起されるリアリテ 々の感覚というものは、映像それ自体の特質によるものではなく、映像化された諸々の対 象の同一性や出来事の分節化された意味を映像之は別の次元で社会的に保証する何らかの 象徴を、再現された映像の中にわれわれが認めたことによって成立する性質のものであろ う。本稿の探究がそのような結論に䡴着するならば、われわれに対する咉像の地位は単に 様々な事象を再現し伝達する透明な媒体（灯仍）にすぎなくなる。しかし、マクルーハンが 言うように、情報伝達の過程ではその情報を運ぶメディアの形式が決定的な役割を果たし ているのならば[McLuhan 1964:訳 7]、また実際に種々のメディアを媒介変数として社会 的な現実か構成され変換されてゆき、われわれの関係の様式が常にメディアという強力な 変数によって規定されているとするならば、わ狆れが映像に見出すリアリティの感覚は、 あくまで映像そ机自体に内在的な特性から分析されなければならない。つまり、わ机れれ は再現された内容にではなく、その再現の形式それ自体に注意を向けなければならないの である。

従って、われわれが映像におけるリアリティの本質をより箃密に分析しようとするなら ば、メッツが指摘したように「映画化された意味作用」と「映画的意味作用」とを明確に 
区別して分析を進めるべきなのである[Mets 1972 : 訳 164]。メッツの言う「映画化され た意味作用」とは、映像化される以前に害質上歷史・文化的に成立している社会的な意味 作用の映像化されたものであり、この場合のシニフィアンは実在する対象の再現された映 像であり、シニフィエは実在する対象がある特定の共同体で既に身に縓っている象徴的な 意味である。従って、この分析は映像の内容分析が取り組むべき事柄に属するだろう。一 方の「映画的意味作用」亡は、映像の表象形態それ自体によって生成する意味作用であり、 この分析は映像の表象としての形態（形式）を分析すると同時に、映像における意味の生 成過程を記述するという作業をも含んでいる。そして、この場合のシニフィアンは実在す る対象の再現された映像そ机自体であり、シニフィエは実在する現実の対象（映像によっ て再現された対象）である。この「映画的意味作用」の分析において焦点を当てられてい るのは、映像と実在する現実の対象との関係であり、そこで問題となっているのは、その 関係によって生成するある種の効果としてのシニフィエである。従って、従来シニフィエ として捉えられていた映像によって表象された対象とは、より厳密に言うならば、もうひ とつのシニフィアンにほかならない。つまり、「映画的意味作用」の分析がその作業仮説 として前提としている、映像それ自体のもつ意味作用の構造を形式的に表現するならば次 のようになるだろう。すなわち、ある特定のシニフィエを成立させているのは、それぞれ のシニフィアンが置かれている他のシニフィアンとの結合関係である、と。換言すると、 それぞれのシニフィアン (映像) と他のシニフィアン (実在の対象) との結合関係か、あ る種の映像的効力としてのシニフィエを発生させるということである[ 小林 1991:164]。 以上のように、あるシニフィエの発生に関して、シニフィアン間の結合関係が常に先尊的 な役割を果たしていると見做すことの帰結として、この分析は映像のエクリチュールある いは文体之情動性之の関連を探究する方向へと進むことになるが、われわれはここで上述 した事柄を想起しなければならない。

すなわち、わ犼れの視覚が言語によって分節化されているということである。そうで あるならば、視覚によって獲得された感覚与件 (sense data)の真偽（信憑性）は言語記号 之同様に決定不能にならざるをえないだ万う。一方そ机に対して映像は、表象としての本 性上その記号表現之記号内容の結びつきが必然的であるために、言語記号のように意味の 決定不能性に陥ることは免れており、それ故に映像の表象機能（誩語的分節化を経ない純 粋な表象機能）とわれわれの視覚の関係を探究するならば、われわれの視覚に関して、意 識に問う限りは決して明かしえないような特質を浮かび上がらせることができるであるう。 但し、映像によって哃起されるリアリティというものが、映像それ自体の特性によるわれ われの感受性に対してのある種の効果であるとするならば、それか映像走見る主体之の関 係において成立するものである限りで、その分析が主体の内面の心理的な次元に関わって くることは必至である。われわ机はここで映像を可読のイメージから転回することを迫ら れているのである。

\section{3. 「視覚的無意識」について}

われわれが映像の記号論的研究から導き出した結論は、映像を可読のイメージから転回 することなしには、映像におけるリアリティの本質を映像それ自体の特性から分析するこ 上はできないということであった。そこでわれわれは本章において、映像によって喚起さ 
れるリアリティの本質を探究するための一つの契機として映像を見るという体験を記述し、 その体験を媒介にして映像そのものの特性と映像に対する主体の地位を分析していく。そ のために、われわれは先ず写真の映像としての表象形態の持つ特性について明らかにする こころから始めたい。何故ならば、写真は光学的に再現された映像の歴史の起源に位置し ており、映像とそれを見る主体とのある根源的な関係をわれわれに示唆するところがある 亡われわれは考えるからである。その根源的な関係とはいかなるものなのか。それがわれ われにとっての最初の問題である。バルトは「「写真」の本質は（もしそれが存在するも のなら）、「写真」によってもたらされた「新しさ」以外のものではありえないっ」[Bar thes 1980:訳 9] として、その「新しさ」の核心を求めて独自の写真論を展開したが、そ れでは写真をそれ以前の（あるいはそれ以外の）表象==再現形式から区別する決定的な

「新しさ」とは何なのか。その「新しさ」の所在を探る上で参考になるのが、ベンヤミン が『写真小史』の中で初めて用いた「視覚的無意識」 [Benjamin 1931: 訳 74] という概 念である。「視覚的無意識」とは写真装置と人間の視覚 (裸眼) との対比を示す概念とし て、カメラによって切り開かれた視覚的な地平を指してそう表現されているのだが、それ ではベンヤミンは、写真装置によって開示された「視覚的無意識」は、人間の視覚が捉え ることのできる風景に比してどのような世界像を出現させたと言うのか。ベンヤミンによ るならば、「カメラに語りかける自然は、眼に語りかける自然とは違う。その違いは、と りわけ、人間の意識に浸透された空間の代わりに、無意識に浸透された空間が現出するよ ころにある。」[Benjamin 1931：訳 74]ここで言われている、カメラによって初めて捉え ることが可能となった「無意識に浸透された空間」とは、いかなる様相を示すものなのか。 それを説明するためにベンヤミンが例として挙げているのは、この小論の五年後に書かれ た『複製技術時代の芸術作品』で再び「視覚的無意識」について言及した際と同様に、日 常の歩行動作というわれわれが常日頃反復しているような、馴れ親しんで半ば自動化して いる所作である[Benjamin 1931：訳 38］。但し、ここで注目すべき点は、ベンヤミンが写 真装置を介して開示されることになった「視覚的無意識」を、精神分析によって明るみに 出された衝動における無意識的なものと相同的な関係にむるものとして捉えている点であ る。

無意識というものは、言語によって表象される過程で、検閲に会い、歪曲されるほかな いものであるということは精神分析によって明らかにされている。それ故に分析家は主体 のどこかに痕跡としてのみ書き込まれている無意識老探り当てねばならないのである。言 い換えるならば、「無意識(das Unbewußte)」というものは、「意識によっては意識され ないもの」として「あくまで否定性という特殊な在り方をする! [小林 1991:96] ものな のであり、その存在は、意識化の徹底という作業によって実体として捉えられるようなも のではなく、あくまで意識によって否定的なかたちで、実際の精神分析の場面では、分析 医に対する患者の転移というかたちで、初めて確認されるといった性質のものなのである。 従って、「視覚的無意識」というものも、それを明示できるような実体としてあるのでは なく、あくまでわれわれ人間の視覚とカメラの視覚との関係を通して露呈するものなので ある。つまり、われわれによって馴れ親しんでいる自然な行動が、カメラの視覚を通じて その自明性を裚失し、意識にとって否定的な性格を帯びた、あるよそよそしさの印象を伴 って、改めてわれわれの前に現れて来るならば、その時われわれが感じ取っているある種 
の違和感こそが、「視覚的無意識」であるということになる。そのような「視覚的無意 識」は、われわれの視覚がカメラの視覚に転移（同一化）することによって初めて確認さ れるのだと考えられるが、クラウスによるならば、視覚における無意識の次元に関して当 然次の上うな疑問か懑起されるという。すなわち、「視覚的領域で、「無意識」そのもの に比較できるようなものについて語ることができるのだろうか。つまり、まず第一に、あ る感覚をもつ存在を前提にし、その内部において作動文る構造で、しかも、第二に、その 存在の意識との葛藤状態にある限りで意味をもつ、そんな構造を考えることができるのだ ろうか。」[krauss 1.993：訳 210] と。われわれはこの疑問を解明することで視覚におけ る無意識の次元を明らかにし、そのことによって写真の「新しさ」を探り当てたい。

ベンヤミンが「視覚的無意識」について言及する際に例として採り挙げた日常の歩行動 作について詳細に分析してみると、そこで触れている視覚における無意識の次元とは、写 真装置が人間の知覚の物理的能力を越えた速度で出来事に反応して、推移する時間の流れ の中から一瞬を記録するという、技術的な達成が開示した次元、つまり人間の視知覚の身 体的な低次機能によっては今まで意識化されえなかった次元を指しているように思われる。 しかもそうした見方が正当な根拠を持つのは、ベンヤミンが高速度撮影、微速度撮影、ク ロース・アップ、ロング・ショット等のカメラの機械としての機能的側面から人間の視覚 に新たに開けた地平の可能性（身体的機能の強化あるいは高度化）を礼讃していることか ら明らかである。しかし、視覚における無意識の次元に関してより本質的な点はほかにあ るのではないだろうか。

松浦寿夫によるならば、20世紀初頭の芸術上の表現に決定的な方向性を与え、その工 ートスを本質的に規定している時代の標徴を取り出すとすれば、[télé-]と[auto-]とい う接頭辞によって表されるだろうと言う［松浦寿夫 1989:164]。[télé-］という接頭辞が あたりに波及させる力学は、「距離を介して存在するいくつもの項が無媒介的に接続しあ う状態」（「相互に遠く隔たった項の接続の操作と、その遠隔性の無媒介化」）［松浦寿 夫 1989:165]へ向けて想像力を刺激し、「共通の平面の創設によって世界を単層的な像へ 乙転換する欲望を顕在化させる」 [ 松浦寿夫 1989:166]こ上にある。世界の無数の〈い ま〉と〈ここ〉からなる出来事の起伏をモニター（ディスプレイ）表面の発光に還元する こと、そのようにして転換された世界像を瞬時に世界中に転送するしいうこと、つまり今 日衛星を介してテレビによって実現されているような状況は、[télé-]という接頭辞が編 成する同時性の力学の圈内にあると言うこよができる。このような速度の力学を讃美した 未来派の推進者であるマリネッティによって発案された「無線的想像力 (imag ination san s fils)」は、[télé-]という接頭辞が示すヴェクトルを象徴的に言い表していると言え る。一方の[auto-]という接頭辞によって喚起される想像力とは、「自動性」を巡って編 成される欲望にほかならないが、この「自動性」の意味するものとは、ブルトンがシュル レアリスムの実践プログラムとして試みた「自動記述(1'écriture automatique)」におい て企図していたところの、思考の純粋な自動的活動 (automat i sme)を表現すること、すな わち主観性の入り込む余地のない完璧に客観的な表象機能の働きのことである。ここでわ れわれが想起する[aut0-]という接頭辞が喚起するところの純粋な自動的活動へと接近し ようとする欲望を具現化する自動機械とは、ほかなら泻真装置である。つまり、[télé 一]という接頭辞が刺激する想像力が速度の美学に帰結するとしたら、[auto-]という接 
頭辞が刺激する想像力はレアリスムの美学を追求すると言えるのである。

ベンヤミンは、未来派の運動の根本的な行動原理である、過去老否定し、文字通り未来 を志向する反時間的態度や、絶対速度を讃美し、生身の身体の物質性が担う鈍重さを愚弄 する反身体的態度には同調せずに、シュルレアリスムの運動を特徴づける、近代的主観に よる内省的な意識を排して、身体と事物との距離をゼロに近づけることで、文字通り事物 の実相をハイパーリアルに浮かび上がらせようとする無媒介的態度や、意識によって統合 的に把握された身体を否認し、ある種の連想形式の現実性を評価して、逆に無意識と化し た身体八と目覚めようとする反形而上学的態度に対してシンパシーを示した。このことか ら判断して、視覚における無意識の次元とは、人間の身体的機能を拡張するという力メラ の技術的な達成が開示した次元を指していると言うよりも、むしろカメラが物の視覚的な 姿を主体の意識の関与しない客観的な視点によって捉えることができるというその非人称 的な次元を指していると言えるのである。

そこで、再度日常の歩行動作について考察してみるならば、ベンヤミンは、われわれが 普段半ば自動的に遂行している歩行動作を、いざ意識してその運動を正確になぞろうとす ると、われわれはその描写が不可能であることに気づかされるだろう、と言うのである。 この半自動的な身ごなしの描写の不可能性は何に対して言われているのか。それはわれわ れが客観的な視点に立って事物を見ることの不可能性に対してであろう。われわれは自ら の生の内部にいる限り、決して客観的な誰のものでもない視点から事物を見ることはでき ない。それは、われわれが自分自身の動作をその外側から傍観者（超越者）の如く見るこ とができないよいう「乗り越えがたい生きられる独我論」[Merleau-Ponty 1945:訳(2)22

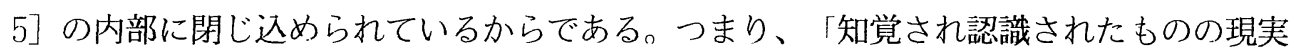
性についての判断を、私は私の内部からしか述べることができない」［新宮 1996:114]な らば、われわれの視覚が捉えた感覚与件 (sense data)のリアリティは、当然疑わしいもの とならざるをえない。そのリアリティが保証されるためには、われわれの外部（普遍的な 場所）からの視線という第三者的な審級が要請されるのである。従って、ベンヤミンが意 図するところの写真によって開示された視覚における無意識の次元とは、写真装置がその 機構上本来的に備えている属性としての自然の事物の完璧な模像（視覚的像）を表象する という「客観性」の位相、われわれ主体の主観的な視覚の外部、誰のものでもない非人称 的な視点を指していると考えることができるのである。

しかし、それではわれれれはまだクラウスによって提示された疑問、主体の意識との葛 藤状態にある限りでその存在が確認されるような、主体の視覚に内在する無意識の構造之 は何か、こいう疑問に答えたことにはならない。そこでこの疑問に答えるとするならは、、 そのような無意識の構造とは、主体の視覚が内包する自己言及の構造であるということに なろだろう。つまり、われわれは自らの視覚によって捉えた感覚与件の真偽を自分自身に よっては判断 (表現) できないという自己言及の困難（すなわち主観による視覚像の信憑 性を支える根拠の不在）に直面せざるをえないのだが、そしてそれがわれわれの意識の言 語的分節構造に由来する自己言及性に起因するということは先述した通りであるが、その 自己言及の無力によって露呈したのは、「見る私（語る私：主観としての私）」と「見ら れる私（語られる私: 客観あるいは他者としての私）」との分裂にほかならない。そこで 明白にされたものとは、われれれ自身の「物自体(das Ding an sich)」としての存在様態 
の位相であろう。思考する私（「見る私」）の存在根拠でありながら、主観性（意識）の 内部に閉じ込妨机ているわ执机によっては、決してその姿を見ることが不可能な「物 自体」としての私の位相。従って、これこそがその無意識であると害体としては指し示す ことができない、主体の視覚の自己言及の構造が浮かび上がらせるわれわれの「物自体」 としての位相、換言するならば、客観的な位相にいる非人称的な「私」、それがクラウス の問いの形に対応する視覚における無意識であるう。

\section{4. 映像の反復性について}

われわ札以上のことから漸く、「写真」によってもたらされた「新しさ」、すなわち その本質とは、「客観性」の位相であると言うことができる。その「客観性」の位相の内 実は、より正確に言うと次の二つの契機から成っている。第一の契機は、カメラの「非中 枢性」である。前田によるならば、われわれ人間は大脳を含む神経系を核とする身体の生 理的な機構の内部に、行動における有用性を前提にした外界からの刺激に対する反応のプ 口セスが組織されており、そのような反応のプロセスが知覚が作動する際に想定されると 言う。前田は、このような中枢神経系の機能在前提とする人間の視覚の在り方（中枢的知 覚)に対して、そういった身体的な中枢神経系を持たないカメラの機構を「非中枢性」之 し、そのような非中怄的な機械であるカメラによる世界の切り取り方、その表象機能を指 して「非中枢的な知覚」と表現しているのである。このように知覚内容を主体の身体的な 行動にとって有用な情報へと縮减する、意識を含媱枢的な機能を備えていないカメラ の視覚とは、誰のものでもない視覚にほかならない。そして前田は、そのような「非中怄 的な知覚」機械であるカメラによって表象された世界は、その即自的な姿である「潜在的 な持続」の相をわれわれの前に開示すると言うのである[ 前田 1996]。

第二の契機は、フィルムの门記録性」である。松浦寿輝によるならば、映像メディアは、 その表象媒体に記録された映像が書き換え可能なもの之書き換え不可能なものものとに分 類されると言う[松浦寿輝 1997:130］。CGのようなデジタル映像は言うまでもなく、ヴ ィデオのように磁気テープをその表象の支持媒体とすることで容易に書き換えが可能な映 像と、写真や映画のように感光フィルムの上に光の明暗を濃淡の織物として即物的に焼き 付けるが故に書き換え不可能な映像とでは、その映像がわれわれのイマジネールを触発し 感覚的に喚起させるある種のエモーションの質に本質的な違いが出てくると言うのである。 そして、映像メディアとしての写真や映画をヴィデオや C G 加本質的に区別する映像そ れ自体に内在する特性は、そのフィルムの上に映像として残されている、表象された事物 の物質的「痕跡」に由来するとされている[ 松浦寿輝 1997:133]。そのようなフィルムの 上に刻印された事物の物質的「痕跡」とは、誰のものでもない記憶にほかならない。この 誰のものでもない記憶としての「痕跡」、ある特定の個人に還元することのできない物質 的記憶が、フィルムの「記録性」の意味するものである。しかしわれわれがそこに見出し たいのは、フィルムの上に刻印された事物の物質的「痕跡」が示す、失われてしまった時 の断片か確かに記録されているという結果としての在り方ではなく、特定の個人に還元す ることのできない物質的記憶の側面、すなわち世界の即自的な姿としての「潜在的な事物 の持続!が含む過去一般の客観的な在り方である。

但し、カメラの「中枢性」とフィルムの「記録性」とが、映像に固有の「客観性」の位 
相を成立させ、それに基づいて映像が客観的な再現力を誇りうるとしても、われわれがそ こに見るべきなのは、寒在の対象とその視覚的模像である映像との形象上の類似性ではな い。何故ならば、二章で述べたように、映像と実在の対象との視覚的性質の類似性を確認 するこよによって喚起されるリアリティの感覚というものは、ある特定の共同体に流通し ているイメージを補強することにのみ奉仕する性質のものだからである。それではわれわ れはそこに何を見るべきなのか。それは、奏在の対象と表象としての映像との「結び付き の確実性」[岡崎 1992:168]を通じて、実在の対象の即自的な在り方か映像それ自体によ って示されるその反復性である。何故ならば、映像を通して対象の即自的な在り方を触知 するという反復の体験によって喚起されるリアリティの感覚は、それこそが映像それ自体 が本性的に内在している特性に由来する映像固有の効果亡呼べる性質のものだからである。 それではその映像独自の効果とはいかなるものなのか。それは、カメラの「非中枢的な知 覚」によってフィルムに刻印された実在の事物の物質的な「痕跡」が、われわれの感受性 にとって疑う余地のない、言わば分節化以前の裸の時間の持続を露呈させるような「客観 性」を、われわれの眼差しに突きつけるということである。以上のことからわれわれは、 映像のリアリティを保証する最終的な審級は、映像と対象(Vファレト)とのある種宿命的とも 吉えるその「結びっきの確実性」にほかならないと言うことができるのである。

\section{5. 映像の「まなざし」について／結びにかえて}

われわれの結論は、映像によって喚起されるリアリティの本質は、映像と対象との確実 な結びつきにあるということである。しかしこのような結論は、映像は実在の事物の視覚 的特徴を人為によらずに精確に表象・再現するからこそ一般に客観的であると判断され、 それ故に映像はリアリティを主張する資格を持つのだという自明の事実を再確認したこと に亡よ゙まるのか。そうではない。それでは映像に打けるリアリティの本質の由来を、映像 と対象との確実な結びつきに求めることの意義はどこにあるのか。その点を明らかにする ために、われわれは映像を見るという体験を成立させている構造に注目したい。それを非 常に簡略化して言えば、「ノエシス的作用」と「ノエマ的表象」とから成っていると言え るだろう［木村 1988:24］。「ノエシス的作用」とは、視覚の作用（知覚活動）そのもの、 すなわち映像を見る一瞬一瞬の現在における視覚の実践的な働きそのものであり、「ノエ マ的表象」とは、視覚の実践的な㗢きが意識に送り込んだ表象であり、すなわちわれわれ の体験における一瞬一瞬の現在に脈絡を与え、全体的なまとまりを構成するために必要之 される時間的空間的に分節化された表象である。以上のことを踏まえた上で、先に検討し た映像の類似性と反復性を例に取りながら、映像におけるリアリティの発生の構造を考察 してみる。映像の類似性によって喚起されるリアリティとは、映像と実在の対象との空間 的なあるいは時間的な距離と、その距離を越えて両者の視覚的性質がどれほど忠実に再現 されているか否かによって判断される、言わば両者の「距離=差異」[松浦寿輝 1994:15 9]を意識化することよって見出される性質のものである。しかし、そのような「距離=差 異」の意識が喚起するリアリティの感覚は、あくまで主体の意識によってノエマ化された 時間空間的表象に由来しているのである。つまり、それはあくまで自分自身の身体感覚を 基点にして、それとの此較考量を経た「距離＝差異」の程度が心理に与える効果をリアリ ティと名付けているのである。それに対して映像の反復性よって喚起されるリアリティと 
は、映像とその対象との結びつき、言わば両者の「あいだ二関係」の確実性に由来して発 生するのであり、そのようなリアリティの感覚は、「あいだ二関係」を構成する諸項に還 元することはできない。それはあくまで「あいだ二関係」それ自体によって喚起されるの である。つまり、そのような「あいだ二関係」の不可分離性に由来するリアリティの感覚 は、映像を見ることを通して対象の即自的な在り方を反復的に体験するという、視覚の) エシス的な知覚活動そのものによって喚起されるある生なましさなのだと言いうる。

ここでわれわれによって示唆的であるのは、バルトがその写真論のおいて、写真がそれ を見る者に対して働きかける作用を、「ノエのないノエシス」と表現していることであ る[Barthes 1980:訳 137]。バルトは同じ著書のなかで、写真の本質はその被写体がかつ て実際に存在していたということを証明する能力にあるとして、写真の映像が示す「それ は二かつて二あった」という写真のノエマ的側面に重点を置いて自らの論を展開している か、それがかつて実在していた事物に笴せる物質的な信頼感によるのでも、映像化された 事物があらゆる実在的な質料性を欠いたシミュラクルと化してしまうことに対するシニカ ルな態度によるのでもないことは明らかである。たとえば、バルトは写真の「存在論」的 性格は、「映像の起源にあるものの現実性」[Barthes 1980:訳 95] と写真の「事実確認能 力（映像の真実性）」[Barthes 1980: 訳 109]との融合、すなわち現実と真実の結合によ って形成されるとして、「「写真」の事実確認性は対象そのものにかかわるのではなく、 時間にかかわる」・「「写真」においては、確実性を証明する能力が、表象=再現の能力 を上まわっている」[Barthes 1980:訳 109]と述べている。それはつまり、われわれによ って写真を見るという体験は、映像とその対象とのどちらか一方に還元されることのない、 両者が強固に結合した結果獲得される映像の「まなざし」 [Barthes 1980:訳 137]によっ て眼差されるという強度の体験にほらならないというこよを意味している。たとえ写真が 過去志向的であり、それ故にそれを見る者をメランコリックな気分へと誘導するとしても、 それは写真の本質的な特性に拠る之言うより、その映像が停止しているというという映像 の形態に起因するものなのであり、それは本来過去を追憶するのでも、「回想の現在性」 [ 岡崎 1995:251]によって時間に序列を持ち込むのでもなく、世界の「潜在的な持続」を 反復することによって、「「時間」の原義」[Barthes 1980:訳 145]を蘇らせるような性 格を持っているのである。このような刻一刻新たに更新される世界の「潜在的な持続」の 現実と真実に触れるという、映像体験のノエシス的側面は、映像におけるリアリティの本 質の由来を、映像亡対象との確実な結びつきに求好ことによって、初めて考察しうるも のとなるのである。何故ならば、そのようなノエシス的局面は、われわれが映像を見ると いう行為とわれわれか映像の「まなざし」によって眼差されるという体験とから構成され ているが、そのような反復的な体験の契機となる映像の「私（われわれ）の目をまともに 見すえる能力」[Barthes 1980:訳 137]は、映像と対象との絶対的な結びつきによって齊 されるからである。

つまり、われわれが映像のリアリティに関して映像と対象との「結びつきの確実性」在 強調するのは、それによって率された映像の「まなざし」に眼差されることによって、わ れわれが世界の「潜在的な持続」の現笑と真実に触れ、そこでわれわれ自身の絶対的な無 力之、それにもかかわらずわれわれは存在したということの確信とを経験する可能性が、 映像それ自体を通して開かれるからである。 
参芳文献

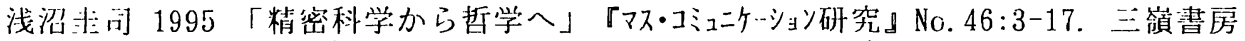
Barthes, R. , 1971, De 1'oeuvre au texte, Introduction a 1' ana1yse structure des Recits, Edition Seui1. 花輪光（訳）「作品からテクストへ」『物語の構造分析』 みすず彗房 1979

, 1980, La chambre claire. Note sur la photographie, Cahiers du Cinéma, Ca11imard, Seui1. 花腀充（訳）「明るい部屋』みすず書房 1985

, 1982, Rhétorique de 1'image, L'obvie et L'obtus, Editions du Seui1. 㳄崳溍平（訳）「映像の修辞学」「第三の意味』みすず書房1984 1982, Le grain de la voix, L'obvie et L'obtus, Editions du Seuil. 沢崎浩平（詐）「声のきめ」『第三の意味』みすず書房1984

Benjamin, T., 1931, K1ein Geschichte der Photographie, Frankfurt, Suhrkamp Verlag KG. 高木久雄・高原宏平（訳）「写真小史」『ヴルター・ベットシ著作集 1 』晶文社 1970

1935-36, Das Kunstwerk im Zeitalter seiner technischen Reproduzierbarkeit, Frankfurt, Suhrkamp Ver1ag KG. 高木久雄・高原宏平（訳）「複製技 術の歭代における芸術作品」『ヴァルター・ベントシ著作集 1 』晶文社 1970

Benveniste, E., 1966, Problèmes de linguistique générale, Paris, éditions Gallimard.

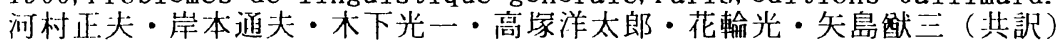
『-般言語学の諸問題』みすず書房 1983

Eco, U., 1968, Cinema e letteratura-La struttura de11' intreccio, in La definizione de11'arte, Milano, Mursia. 米川良夫（訳）「映画と文学」『ユリイカ』 第 7 卷第 7 咢: 78-84. 青土社 1997

藤们真文 1995 「咉像の記号諭的解积と反＝記号論的解䊅」『マス・コミュニケーション研究』No. 46: 72-86. 三镇書院

Kant, I. , 1787, Kritik der reinen Vernunft. 筗田英雄（訳）「純粋理性批判』上・中・下 亚波文連 1961

Kierkegaards, S. 1843, Gjentage1sen. 桝田啓三郎（訳）「反復」「筑摩世界文学体系32』 筑摩書房 1973

木村儌 1981 『白已・あいだ・時間」弘文堂

—— 1988 『あいだ』弘文堂

小林敏叮了1991「精神坊理からみた現代思想』掯談社現代新書

Krauss, R., 1993. The Optical Unconscious, NIT Press. 小俣出美・鈴木真理子・田崎英明 （訳）「視覚的無意識（第 4 章）」『批評空間』臨時増刊号:193-223. 福武書店 1995

MacLuhan, M., 1964, Understanding Media:The Extension of Man, New York, McGraw-Hi11 Book Company. 栗原裕・河本仲聖（訳）『メディア論』みすず書房1987

前以炎樹 1996 『イマージュの秘靕』青土社

忪浦寿耀 1994 『平面諭』岩波書店

— 1997 『ゴダール』筑摩書房

忪浦替夫 1989 「絵画の变貌、矨覚の变貌」『講座・20世紀の芸術 第 4 巻』岩波書店

Merleau-Ponty, M. , 1945, La Phénoménologie de la Perception, Paris, Edition Gálimard 竹内芳郎・术任元・宮本忠雄（訳）『知覚の現象学』みすす書房1974

Metz, C., 1964, Le cinéma: langue ou langage?, in Communication No4. 箖岡祥論 (訳) 岩本畫児（編）「炚画一言語体系か、言語活動か?」『映画埋論集成』 フィルム・アート社1982

- 1972, Essais sur la signification au cinéma, tome 2, Paris, éditions Klincksieck. 浅沼圭司（監訳）『映画記号学の諸問題』水声社1987

阔崎乾 :郎 1992 「信仰のアレゴリー」，『批評空間』4 号:180-193. 福武書店 - 1995 「経験の条件」, 『批評空間』臨時增刊号: 246-261. 福武書店

Peirce, C.S. 1868, Collected Papers of Charles Sanders Peirce Vo1. 5, The Belknap Press of Harvard University Press, 1978. 内田種臣（編訳）勁草書房 1986

1897, Collected Papers of Charles Sanders Peirce Vo1.2, The Be1knap Press of Harvard University Press, 1978. 内田種臣（編訳）勁草書房 1986

Saussure, F. de., 1916, Cours de Linguistique général, publié par Charles Bally et Albert Sechehaye, 1949. 小林英夫（訳）「一般言語学溝義』岩波書店 1972

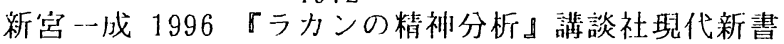

